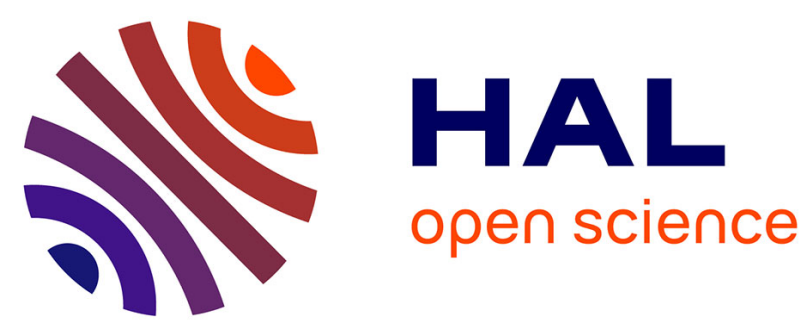

\title{
Business Games Based on Simulation and Decision-Making in Logistics Processes
}

Marco Aurelio Butzke, Anete Alberton, Jeancarlo Visentainer, Solimar Garcia, Irenilza De Alencar Nääs

\section{- To cite this version:}

Marco Aurelio Butzke, Anete Alberton, Jeancarlo Visentainer, Solimar Garcia, Irenilza De Alencar Nääs. Business Games Based on Simulation and Decision-Making in Logistics Processes. IFIP International Conference on Advances in Production Management Systems (APMS), Sep 2017, Hamburg, Germany. pp.91-98, 10.1007/978-3-319-66926-7_11 . hal-01707255

\section{HAL Id: hal-01707255 \\ https://hal.inria.fr/hal-01707255}

Submitted on 12 Feb 2018

HAL is a multi-disciplinary open access archive for the deposit and dissemination of scientific research documents, whether they are published or not. The documents may come from teaching and research institutions in France or abroad, or from public or private research centers.
L'archive ouverte pluridisciplinaire HAL, est destinée au dépôt et à la diffusion de documents scientifiques de niveau recherche, publiés ou non, émanant des établissements d'enseignement et de recherche français ou étrangers, des laboratoires publics ou privés. 


\title{
Business games based on simulation and decision- making in logistics processes
}

\author{
Marco Aurelio Butzke ${ }^{1[0000-0002-8809-3568]}$, Anete Alberton ${ }^{2[0000-0002-6477-0122]}$, , \\ Jeancarlo Visentainer ${ }^{10000-0001-7707-9122]}$, Solimar Garcia ${ }^{3[0000-0002-5807-8041]}$ and Irenilza \\ de Alencar Nääs3[0000-0003-0663-9377] \\ ${ }^{1}$ Centro Universitário para o Desenvolvimento do Alto Vale do Itajaí (Unidavi), Rio do Sul, \\ Brazil \\ $\{$ marco,jv\}@unidavi.edu.br \\ ${ }^{2}$ Universidade Vale do Itajaí (Univali), Itajaí, Brazil \\ \{anete@univali.br\} \\ ${ }^{3}$ University Paulista (Unip), São Paulo, Brazil \\ \{solimargarcia10, irenilza\}@gmail.com.
}

\begin{abstract}
The use of business games can help us-ers to find solutions to complex management problems, to develop critical and strategic thinking skills, and to prepare professionals for the labor market. Business games as an active learning method has been widely debated, and there is a continuing interest in how students learn when they are stimulated. The goal of this research is to analyze the application of business games as an effective teaching methodology and decision-making in logistics processes in business administration undergraduate courses. The business game ENTERSIM was built with software and cloud computing. As the results, the students's testimo-nies showed some deficiencies in the instructions given and in the activity appli-cation's time. However, students emphasized the wish to carry out again activities that involve business games for bringing theory to practice. Students recognized the contribution of the business game to improve learning about operations, problem-solving, and decisionmaking.
\end{abstract}

Keywords: Business Games, Active Methodologies, Logistics Processes.

\section{Introduction}

Business games can improve student learning and prepare them for the labor market to create environmental experiences to offer them an opportunity to learn how to do it $[3,6]$. Business games aim to collaborate in the teaching-learning process when the proposed environment is risk-free, offers realism and allows responses with immediate feedback.

The relationships between supply, plant and distribution processes by activities of storage, transport, movement and distribution of logistics products can be considered complex and involve strategic, tactical and operational levels. Besides, the complexity 
Business games based on simulation and decision-making in logistics processes

of these relations can raise results in the organizational performance. In this way, decisions made in the logistic processes must be integrated and systematized to reduce costs or to make tradeoffs [1].

According to authors [7], some issues can be discussed about the use of business games as an effective teaching methodology to improve decision-making for training in management processes. What the criteria of success with the use of business games and the relationships of business games with other teaching methodologies are the author's questions.

This research paper intends to implement a business game based on simulation, with the incorporation of challenges with goals for the performance indicators and decision model to define the sequence of decisions related to organizational levels. Lastly, the main purpose is to analyze the application of business games as an effective teaching methodology and decision-making in logistics processes in business administration courses.

\section{Decision-making in logistics processes in business games based on simulation}

The search for answers to what are the criteria of success with the use of business games and the relations with other subjects in the teaching of business administration have been significant challenges to be overcome [7]. To authors [6], the goal is to create an instructional program that incorporates resources and features of the game. The reactions and judgments of the participants are caught during the game, and at the end, it must have the commitment to validate if the learning objectives have been achieved.

The some authors [6] consider the results pointed out by students in business games based on simulation for the learning process: interest, pleasure, involvement, confidence, behavior, feedback and debriefing (Table 1). The authors conclude that a business game based on simulation should be fun, interesting and engaging, and beyond learning, it should be considered as entertainment that builds trust and spontaneous participation of the student. When well designed, a game can facilitate the learning of specific concepts and skills by solving problems with decision-making.

Business games based on simulation have been used in the classroom to support in the teaching and learning process since the 1950s [5]. The use of business games as a pedagogical support tool to modernize classes and the implementation of information technologies has improved the process of disseminating simultaneous results with immediate feedback.

According to authors [8], the use of simulation can contribute to strategic and tactical decisions to improve financial performance. In [2] introduced a scheme that incorporates a production system with the view of a decision model through the GRAI grid that aims to provide a generic description of a production system, focusing on the control of point of view. The control of a production system will be represented from a global perspective, at the decision center level. 
Table 1. Determinant factors for learning with business games

\begin{tabular}{ll}
\hline Factor & Characteristics \\
\hline Relevance & $\begin{array}{l}\text { The business game must be more interesting than the traditional teaching } \\
\text { strategies with the possibility of offering a real simulated environment } \\
\text { bringing theory to practice. }\end{array}$ \\
Business games must be fun and enjoyable, combining challenge, learning, \\
and retention of knowledge.
\end{tabular}

The Development of the GRAI grid modeling started from a theoretical basis. At the conceptual level, the model is composed of three systems: the physical system, the decision system and the information system (Figure 1).

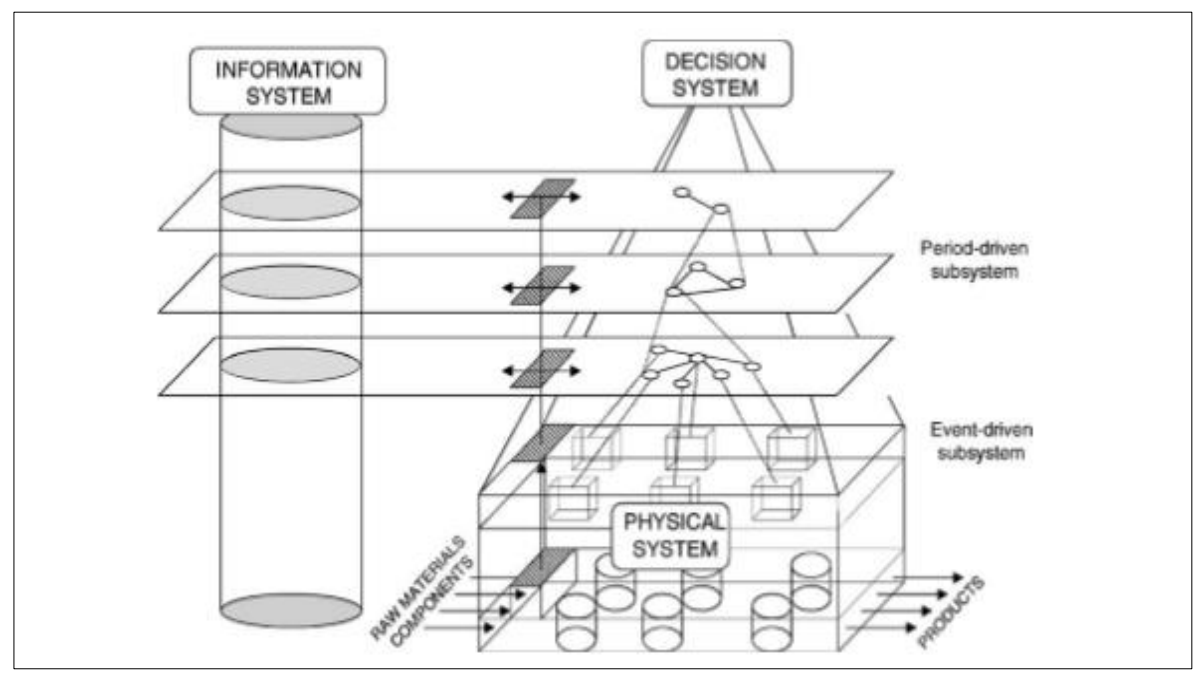

Fig. 1. The GRAI Model

Source: [2].

In this research, the information system used is the business games based on simulation. Besides, it was used the grid diagram to build the menu of options for students to operationalize their decisions at the strategic, tactical and operational levels. 
Business games based on simulation and decision-making in logistics processes

The simulation of the results from the decision-making process to help students in the learning process or the training of professionals for the labor market can occur through the application of business games. Therefore, a system based on a decision model can be used to facilitate the visualization and organization of the decisionmaking process. However, some authors point out that the existing relations, both operational and informational, between the hierarchical levels can raise difficulties in the decision-making process. In this scenario of complexity, decisions must be made in a systematic and integrated way.

The logistics processes of supply, plant, and distribution are logistics costs generators through physical operations of packing, transport, storage and handling between the factories and the values inherent to the chain functioning such as maintaining inventory, information technology, taxation and failures [4]. Furthermore, logistics costs tradeoffs are compensatory tradeoffs between costs and the level of service provided to the customer and interfere with the company's economic and financial performance [9]. Likewise, according to [1], professionals know that logistics costs tradeoffs do exist, but they do not clearly have the idea that the total cost is determined by them.

Regarding the implementation of the organization for the decision-making process in the ENTERSIM business game (Table 2), the GRAI grid Methodology was used according to the studies developed by [2].

Table 2. Logistic decision proposed for the business game based on simulation

\begin{tabular}{|c|c|c|}
\hline $\begin{array}{l}\text { Logistic } \\
\text { process }\end{array}$ & Decision & Description \\
\hline \multirow{3}{*}{ Inbound } & Selection of suppliers & $\begin{array}{l}\text { The student can choose three suppliers to buy raw } \\
\text { material. }\end{array}$ \\
\hline & Modal of transport & $\begin{array}{l}\text { The student must select a modal (road, rail, air or } \\
\text { sea) to carry the raw material. }\end{array}$ \\
\hline & $\begin{array}{l}\text { Lot for acquisition of } \\
\text { raw material }\end{array}$ & $\begin{array}{l}\text { The quantities (lots) offered by the selected } \\
\text { suppliers and stocks of raw material can be } \\
\text { checked. }\end{array}$ \\
\hline \multirow[t]{2}{*}{ Plant } & Plant location & $\begin{array}{l}\text { The student must choose the location of the factory } \\
\text { plant among the } 27 \text { capitals of Brazilian states. The } \\
\text { revenue from the chosen capital will be ignored to } \\
\text { calculate the indicators. }\end{array}$ \\
\hline & Manufacturing planning & $\begin{array}{l}\text { The student can define the product in each } \\
\text { production unit on the business day. }\end{array}$ \\
\hline \multirow{3}{*}{ Outbound } & Freight & The student can choose CIF or FOB for delivery. \\
\hline & Modal transport & $\begin{array}{l}\text { The student must select a modal (road, rail, air or } \\
\text { sea) to transport the finished goods. }\end{array}$ \\
\hline & Revenue of orders & $\begin{array}{l}\text { The student will define the day of delivery and } \\
\text { control the finished goods inventory. }\end{array}$ \\
\hline \multirow[b]{2}{*}{ Inventory } & Raw material inventory & The student can check raw material inventory. \\
\hline & $\begin{array}{l}\text { Finished goods } \\
\text { inventory }\end{array}$ & The student can check finished goods inventory. \\
\hline
\end{tabular}

Source: the authors (2017).

The values for the indicators were calculated using the values for the costs involved in logistics processes, expenses, stock inventory, and gross revenue. Table 3 shows the 
performance indicators classified by the logistic process, a key factor, and attribute. The authors [10] state that the use of a simulated environment, without risk and losses in decision-making, can contribute to analyzing events and their impacts influence on organizational performance.

Table 3. Performance of indicators at the business game

\begin{tabular}{clllc}
\hline $\begin{array}{c}\text { Logistic } \\
\text { process }\end{array}$ & $\begin{array}{l}\text { Key- } \\
\text { factor }\end{array}$ & Attribute & Indicator & Measure \\
\hline & Factory & Efficiency & Raw material level & $\%$ \\
& Inventory & Efficiency & Raw material efficiency & $\%$ \\
Inbound & & Cost & Inbound cost & $\%$ of income \\
& Transport & Cost & Raw material cost & $\%$ of income \\
& & Responsiveness & Delivery time & days \\
Plant & \multirow{2}{*}{ Factory } & Cost & Rental cost & $\%$ of income \\
& & Efficiency & Finished goods level & $\%$ \\
& & Cost & Internal cost & $\%$ of income \\
Outbound & Inventory & Efficiency & Finished goods efficiency & $\%$ \\
& & Cost & Outbound cost & $\%$ of income \\
& \multirow{2}{*}{ Transport } & Responsiveness & Delivery time & days \\
& & Efficiency & Orders & orders \\
\hline
\end{tabular}

Source: the authors (2017).

The scenario chosen for the application of the business game was the simulation of an environment of a textile industry from the point of view of the analysis and the influence of logistics costs based on the processes of supply, plant and distribution. The use of simulation, optimization and decision models in business games serves to assist students in the teaching and learning process for decision-making. The complexity of costs and tradeoffs in logistics processes create performance indicators that will be used as a basis for training new managers.

\section{Methodology}

The research was carried out in three steps: structure, application, and analysis of the data to evaluate the relationship between aspects of active teaching methods and student performance in the application of a business game based on simulation at a decision-making scenario in logistics process. The first step, the structure one, was related to the literature review on active learning, business games based on simulation, logistics costs, and decision-making in logistic processes. Besides, with this information, activities for the field research involving the use of business games, the research instruments for the data collection and sampling were designed.

Regarding the second step, the research application, it was subdivided as follows: to enable students participating in the game and register the personal characteristics; to train students for taking part in the game through instruction in order to perform basic operations in the business game; to apply inventories to measure learning styles; to apply the research instrument about the learning facilitating factor; to apply the research 
Business games based on simulation and decision-making in logistics processes

instrument for validating the learning environment quality; and to apply the business game based on simulation. Furthermore, the third step was to analyze the gathered data.

The application was carried out at UNIDAVI at 2 undergraduate courses: business administration (with 95 students) and international trade (with 27 students). The application process totalized 122 samples for data analysis.

Moreover, when accessing the business game, the student could access the decisionmaking options in logistics processes such as plant location, manufacturing planning, selection of suppliers, modal transport, a lot of raw material acquisition, freight and revenue of orders. The business game presented the performance indicators in the logistics processes of inbound, plant and outbound classified by cost, efficiency, and responsiveness. The student can verify the impact on performance indicators in each decision made in the logistics processes.

Furthermore, from the collected variables and definition of constructs data were validated. The performance of the student in the business game did not present significant differences in the perception of the learning facilitating factors, excepting for the aspects related to the classroom environment. Regarding the learning environment quality, there was no significant difference between the evaluated factors.

After analyzing the results, it was necessary to investigate some points that presented the best and the worst results in the participants' responses. The points that needed to be investigated were: the learning facilitating, in the dimensions of teaching strategy and reflection in action; and also on the quality of information in the instrument that evaluated the learning environment. Therefore, for this process were selected business administration students with better and worse outcomes at the business game, a total of fifteen students. Considering the invited students, eight accepted to participate in another data collection through individual questions and personal testimonies about the experiment they had participated.

About this step, an interview script was designed to gather students' testimony on the issues that presented the most relevance to improving understanding in a subjective way. The script had the following questions: 1 - Would you use a business game again? Was the time for the activity appropriate? 2 - Did the business game contribute to your learning? Did the business game associate theory with practice? 3 - Regarding the instructions provided, do you think they can be improved? 4 - Did the business game provide information to improve your knowledge about a company's operation or problem-solving? 5 - Did the business game help in discussing problems and solving conflicts in the group? 6 - Can the business game improve my knowledge about decision-making?

\section{Data analysis}

The quality of the virtual environment for learning in the business game presented a better result in the indicators of satisfaction about the perception of the student on perceived utility. Likewise, the quality of information indicated a significant difference when related to performance. The ease-of-use factor showed below-average performance and the variable about "interacting with business games did not require much intellectual effort" had a discordance index of $14 \%$. This indicator reflects the complexity involved in choosing the scenario for designing the business game based on decision-making in logistics processes. 
Considering the variable "to help integrate learning in several areas", it obtained good indicators. Then the variable "helps to know the activities related to the professional practice" was well evaluated in this research and did not obtain good indicators in the previous researches. Additionally, this result may consider that the ENTERSIM business game associates theory to practice regarding students' perceptions about the labor market. The factors evaluated in this study about the learning facilitators presented agreement indexes between $35 \%$ and $64 \%$ in all variables.

Concerning the students' voluntary testimony, it can be observed that all of them would participate again in activities with business games. However, the time available to perform the activity was divergent among students, with a tendency to affirm that the application time was not enough. "Yes, I would, but the time was not sufficient. As the software is broad and involves some processes it takes time", reported A5. Disagreeing with this statement, A8 reports that "I would play whenever available and the time was enough for me."

There was a strong demonstration of the students about the contribution to the learning process since it connects the theory to the practice. The responses show that everyone agrees, but A6 points out that there were many doubts during the process, and A7 states: "With more time, I could make enjoy it better." Therefore, in the opinion of the students, the business game can help in the decision-making process. However, they emphasized that it just happens with a clear understanding of the operation and routines contained in the activity.

Regarding company's operations and problem-solving, there was agreement and consciousness of some respondents that decisions might influence the indicators more than others: "any details can lead to great impacts" reports A8. Likewise, in the group discussions, A6 mentioned that he preferred to play individually. Except for A2 and A3, the others reported that there were discussions in the group; there is information about disagreement and consensus in the group. Considering the contribution of the game to learning in the decision-making process, all students agreed with the relevance of this methodology. Although, A6 and A7 report that only with the clear understanding of the entire decision-making process the business game contributes to the apprenticeship.

\section{Final remarks}

Business games have been used as a teaching strategy in universities for decades. Since the beginning, the discussion about the use this active learning methodology, impacts and contribution in teaching business administration has raised studies that demonstrate the importance of the evolution of business games adapting itself to the innovations of information and communication technologies.

Furthermore, for most students that participated on the voluntary testimony, instructions can be improved. Group discussions and conflict resolution did not obtain defined patterns, and it was observed that each group had its behavior. Although the gathered results highlighted some difficulties and suggestions for improvements: in general, the application of the game contributed to the learning process; and it was also considered a teaching strategy that contributes to the development of reasoning in 
decision-making, problem-solving, as well it brings theory to practice. The students' statements validate the results presented previously by [6].

In conclusion, the ways in which business games have been used on updated technological platforms have allowed changes on the interaction development as well as about the immediate feedback on decision-making results. Lastly, these aspects motivate students to participate more actively in the learning process and to interact with educational tools. All of this is possible due to the Internet and cloud computing associated to friendly interfaces together with the independence of geographical location and time zones.

Acknowledgment: The authors wish to thank CAPES and CNPQ, and the Universitat Politècnica de València (UPV).

\section{References}

1. AMARAL, J. V.; GUERREIRO R.: Conhecimento e Avaliação dos trade-offs de Custos Logísticos: Um estudo com profissionais brasileiros. ENANPAD. Rio de Janeiro, Brasil (2013).

2. DOUMEINGTS G.: Méthode GRAI: méthode de conception des systémes en productique (Thése d'état: Automatique: Université de Bordeaux 1) (1984).

3. DOYLE D.; BROWN, F. W.: Using a Business Simulation to Teach Applied Skills-The Benefits and the Challenges of Using Student Teams from Multiple Countries. Journal of

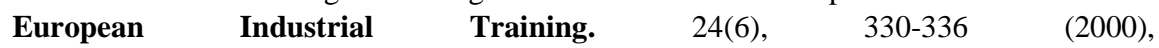
http://dx.doi.org/10.1108/03090590010373316.

4. FARIA A. C.; COSTA, M. F. G. Gestão de Custos Logísticos. São Paulo: Atlas (2010)

5. FARIA, A. J.; HUTCHINSON, D.; WELIIGNTON, W. J., \& GOLD, S.: Developments in business gaming: A review of the past 40 years. Simulation \& Gaming, 40, 464-487 (2009) DOI: $10.1177 / 1046878108327585$.

6. GARRIS, R.; ASHLERS, R.; DRISKELL, J. E. Games, motivation, and learning: A research and practice model. Simulation \& Gaming, 33(4), 441-467 (2002), DOI: $10.1177 / 1046878102238607$.

7. GONEN, A.; BRILL, E.; FRANK M.: On-line training for Improvement of Business Decision. IEEE, 08, 1253 (2008), http://dx.doi.org/10.1108/10748120910998434.

8. HARRINGTON, T. C.; LAMBERT, D. M.; STERLING, J. U.: Sterling, Simulating the Financial Impact of Marketing and Logistics Decisions, International Journal of Physical

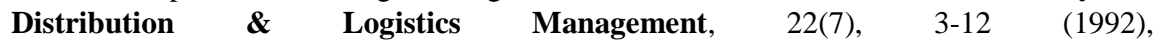
http://dx.doi.org/10.1108/09600039210022024.

9. LAMBERT, D.M.; ARMITAGE, H. M.: Distribution costs: the challenge: The key to managing the physical distribution function is total cost analysis, rather than aphazard stabs at cutting specific costs. Management Accounting. Montvale, 60(11), 33-37 (1979).

10. MELNYK, S. A.; RODRIGUES A.; RAGATZ, G. L.: Using Simulation to investigate Supply Chain Disruption. In: Supply Chain Risk: A handbook of Assessment, Management, and Performance (2008). 